\title{
Eficiencia fotoquímica del fotosistema II en plantas de brócoli (Brassica oleracea var Italica) afectadas por exceso de hierro
}

\author{
Photochemical efficiency of photosystem II (PSII) in broccoli \\ plants (Brassica oleracea var Italica) affected by excess iron
}

\author{
Eficiência fotoquímica do fotossistema II em plantas de brócolis \\ (Brassicaoleracea var Itálica) afetadas por excesso de ferro
}

\author{
Jaime E. Peña-Olmos ${ }^{1}$, Fánor Casierra-Posada ${ }^{2}$
}

\begin{abstract}
Agronomist, MSc, Plant Ecophysiology Research Group, Secretaría de Educación de Bogotá.
Agronomist, PhD, Plant Ecophysiology Research Group, Faculty of Agricultural Sciences, Universidad Pedagógica y

Tecnológica de Colombia (UPTC). Tunja (Colombia)

Email: jaime.pena@uptc.edu.co
\end{abstract}

Recibido: marzo 06 de $2012 \quad$ Aceptado: mayo 16 de 2013

\begin{abstract}
Resumen
Utilizando un diseño completamente aleatorizado, con tres tratamientos y siete repeticiones por tratamiento, se determinó la fluorescencia de la clorofila a en plantas de brócoli sometidas a toxicidad por hierro. Como material vegetal inicial se tomaron plántulas de brócoli (Brassica oleracea var. Italica) híbrido Legacy de un mes de edad, las que se sembraron en contenedores de vidrio con una solución nutritiva, bajo invernadero en Tunja - Colombia. Aproximadamente tres semanas después del transplante se adicionó sulfato de hierro en concentraciones de 100 y 250 ppm de Fe, con un control sin aplicación de sulfato de hierro, para inducir reacciones de las plantas al exceso del metal. Diecisiete días después de las aplicaciones de Fe se realizaron las mediciones de fluorescencia de la clorofila, en hojas completamente expandidas y adaptadas a la oscuridad. El análisis de varianza encontró diferencias significativas para todas las variables evaluadas, excepto para el coeficiente de extinción no fotoquímica (qN). Los resultados indican que la toxicidad por exceso de hierro indujo un incremento en el nivel de estrés en las plantas de brócoli evaluadas, lo que afectó la eficiencia cuántica máxima y el rendimiento fotoquímico operacional del PSII ( $F_{v} / F_{m}$ y $\Phi I l$, respectivamente), al igual que el coeficiente de extinción fotoquímica de la fluorescencia (qP) y la tasa de transporte de electrones. Con lo anterior, es evidente que el exceso de hierro modificó la fracción de energía de excitación destinada para los procesos fotoquímicos y no fotoquímicos, incidiendo de forma directa en el proceso fotosintético de las plantas evaluadas.
\end{abstract}

Palabras clave: capacidad fotosintética, captura de luz, centros de reacción, exceso de energía, fotoinhibición.

\begin{abstract}
Acompletely randomised design, having three treatments and seven repeats per treatment, was used for determining chlorophyll a fluorescence in broccoli plants affected by iron toxicity. One month old Legacy hybrid broccoli seedlings (Brassica oleracea var. Italica) were taken as initial vegetal material and sown in a greenhouse in Tunja, Colombia, in glass vessels containing a nutritive solution. Iron sulphate at 100 and 250 ppm Fe concentration was added about three weeks
\end{abstract}


after transplanting (as well as control with out iron sulphate) for inducing reactions to the excess of metal in the plants. Chlorophyll fluorescence was measured in leaves which were fully expanded and adapted to the dark seventeen days after applying Fe. Analysis of variance (ANOVA) revealed significant differences for all the variables evaluated in this study, except for the coefficient of non-photochemical quenching $(\mathrm{qN})$. The results showed that toxicity caused by an excess of iron induced an increased level of stress in the broccoli plants evaluated here, there by affecting photosystem II's (PSII) maximum quantumyield $\left(\mathrm{F}_{\mathrm{v}} / \mathrm{F}_{\mathrm{m}}\right)$, PS II operating efficiency $(\Phi \mathrm{II})$, coefficient of photochemical quenching $(\mathrm{qP})$ and electron transport rate. The foregoing makes it evident that an excess of iron modified the fraction of excitation energy destined for photochemical and non-photochemical processes, thereby having a direct impact on photosynthesis in the plants evaluated here.

Key words: photosystem II (PSII), photosynthetic capacity, light capture, photosynthetic reaction centre, excess energy, photo-inhibition.

\begin{abstract}
Resumo
Usando um delineamento experimental inteiramente casualizado, com três tratamentos e sete repetições por tratamento, determinou-se a fluorescência da clorofila a em plantas de brócolis submetidas à toxicidade de ferro. Como o material inicial foram tomadasmudas de brocolis (Brassica oleracea var Itálica) Híbrido Legacy de um mês de idade, que foram plantadas em recipientes de vidro com uma solução nutritiva em casa de vegetação em Tunja - Colômbia. Cerca de três semanas após o transplante foi adicionado sulfato de ferro em concentrações de 100 e 250 ppm de Fe, com um controle sem aplicação de sulfato de ferro para induzir reações das plantas ao metal em excesso. Dezessete dias após as aplicações Fe foram realizadas medições de fluorescência da clorofila em folhas completamente expandidas e adaptadas a escuridão. A análise de variância foram encontradas diferenças significativas para todas as variáveis avaliadas, exceto para o coeficiente de extinção não-fotoquímica $(q N)$. Os resultados indicam que a toxicidade por excesso de ferro induziu um aumento no nível de estresse nas plantas de brócolis avaliados, afetando a eficiência quântica máxima e o desempenho fotoquímico operacional do PSII (Fv / Fm e ФII, respectivamente), do mesmo modo que o coeficiente de extinção fotoquímica da fluorescência (qP), e a taxa de transporte de electrões. Com o acima exposto, é evidente que o excesso de ferro modificou a fração energia de excitação destinada a processos fotoquímicos e não fotoquímicos participando diretamente no processo de fotossíntese nas plantas avaliadas.
\end{abstract}

Palavras-chave: capacidade fotossintética, captura de luz, centros de reação, excesso de energia, foto inibição.

\section{Introduction}

Iron is an essential plant nutrient; its functions include accepting and donating electrons, and it plays an important role in the electron transport chain for both photosynthesis and respiration. Nevertheless, at certain high levels of soil accumulation iron becomes toxic to plants. Iron can act catalytically through Fenton's reaction to generate hydroxyl radicals that damage fats, proteins, and DNA (Connolly and Guerinot, 2002). There is evidence that high iron concentrations can influence growth and distribution of plant species both in dry zones (Waldren et al., 1987) and humid zones (Talbot et al., 1987).

Iron toxicity is often seen in irrigated crops as a result of excess soluble iron in irrigation water (Ponnamperuma, 1976). Iron toxicity is widely distributed in Asian, African, and South American soils (Sahrawat, 2004). In this sense, the phenomenon has been studied mainly in rice, due to the high levels of iron found in poorlydrained acid soils subjected to flooding prior to planting (De Oliveira-Camargo, 1984). Some species of Asian rice (Oryza sativa) are sensitive to high levels of iron, especially in its ferrous form $\left(\mathrm{Fe}^{2+}\right)$, and this sensitivity manifests itself in symptoms such as bronzing of older leaves, reduction in leaf growth and tillering, nutritional imbalances, and overproduction of ethylene (Majeruset al., 2007).

Colombia possesses many cultivable soils, of which almost all are affected by some problem such as deficiency or toxic excess of certain plant nutrients. In Colombia there are areas of lime soils with an excess of mineral salts, which impede the normal development and growth of cultivated plants. Large areas of the Caribbean plain, the Magdalena and Cauca floodplains, and the high altitude plains, which is to say the major farming zones of the country, are susceptible to salinization (Casierra-Posada et al., 2007). On the other hand, almost 67 million hectares in Colombia consist in acid soils affected by iron and aluminum toxicity (Casierra-Posada et al., 2008), and this is perhaps the major limiting factor for crop growth in different regions throughout the country (Malagón-Castro, 2011).

The savannahs of the Eastern Plains (also known as the Colombian Orinoco region) occupy some 17 million hectares (Molina et al., 2003), of which 3.4 million hectares of flat land that could otherwise be used for mechanized agriculture possess Oxisols and other soils 
with a $\mathrm{pH}$ of 4.5 , low availability of $\mathrm{Ca}, \mathrm{Mg}, \mathrm{K}$, and $\mathrm{P}$, and high Al content (Flor, 2010; Rodríguez-Atehortúa et al., 2010; Cochrane y Sánchez, 1981). These soils are highly susceptible to degradation, and under natural conditions offer a poor medium for production of crops and pastures (Amézquita, 1998).

Despite the important plant growth limitations caused by iron excess in Colombian soils (Gómez et al., 2007), there has been little experimentation on this topic. In fact, much global research occurs in temperate zones with lime soils, where iron deficiency and not excess is the more common problem (Prasad, 2003). But the fact remains that growth and yields of the world's principal crops are drastically reduced by an excess of this transition metal. For example, rice cultivation in a large swathe of humid lands in Africa, Asia, and South America is strongly affected by the generalized nutrient imbalance brought on by iron toxicity (Majeruset al., 2007). Because of this, plant physiological aspects should be studied to understand the tolerance of different species to iron excess. The objective of the present study is thus to evaluate the behavior of broccoli plants exposed to differing levels of iron in the growing medium.

\section{Materials and methodology}

The experiment was carried out in a glass greenhouse belonging to the Faculty of Agricultural and Animal Sciences at the UPTC University in Tunja, Colombia.
Average temperature inside the greenhouse was 15.8 ${ }^{\circ} \mathrm{C}$, relative humidity was $72.0 \%$, and photosynthetically-active radiation (PAR) was $650 \mu_{\text {molm }}^{-2} \mathrm{~s}^{-1}$.

Planting material consisted in one-month-old broccoli plantlets (Brassica oleracea var. Italica) of the hybrid Legacy. These were planted in glass containers containing a nutrient solution with the following composition in $\mathrm{mg} \mathrm{L}^{-1}$ : nitrate nitrogen 40.3; ammonium nitrogen 4.0; phosphorus 20.4; potassium 50.6; calcium 28.8; magnesium 11.4; sulfur 1.0; iron 1.12; manganese 0.112 ; copper 0.012 ; zinc 0.0264 ; boron 0.106 ; molybdenum 0.0012 ; and cobalt 0.00036 . Twenty days after transplanting iron sulfate was added to the plant to induce metal excess, in concentrations of 100 and 250 ppm, with a control that received no iron sulfate excess. Solution $\mathrm{pH}$ was 6.2 for the control, 5.5 for the $100 \mathrm{ppm}$ iron treatment, and 5.3 for the $250 \mathrm{ppm}$ treatment. The excess iron was added gradually over 20 days to avoid plant shock.

Chlorophyll fluorescence was measured 37 days after transplanting in dark-adapted leaves at ambient temperature using a Junior-PAM fluorometer (Walz $\mathrm{GmbH}$, Effeltrich, Germany). An actinic pulse of 820 $\mu$ molm ${ }^{-2} \mathrm{~s}^{-1}$ was used. Initial fluorescence $\left(\mathrm{F}_{\mathrm{o}}\right)$, maximum fluorescence $\left(F_{m}\right)$, effective photochemical quantum yield of photosystem II or $\Phi$ II, quantum yield of lightinduced non-photochemical quenching or $\mathrm{Y}(\mathrm{NPQ})$, quantum yield of non-light-induced non-photochemical quenching or $\mathrm{Y}(\mathrm{NO})$, electron transport rate (ETR), a photochemical quenching coefficient $(\mathrm{qP})$, and non-

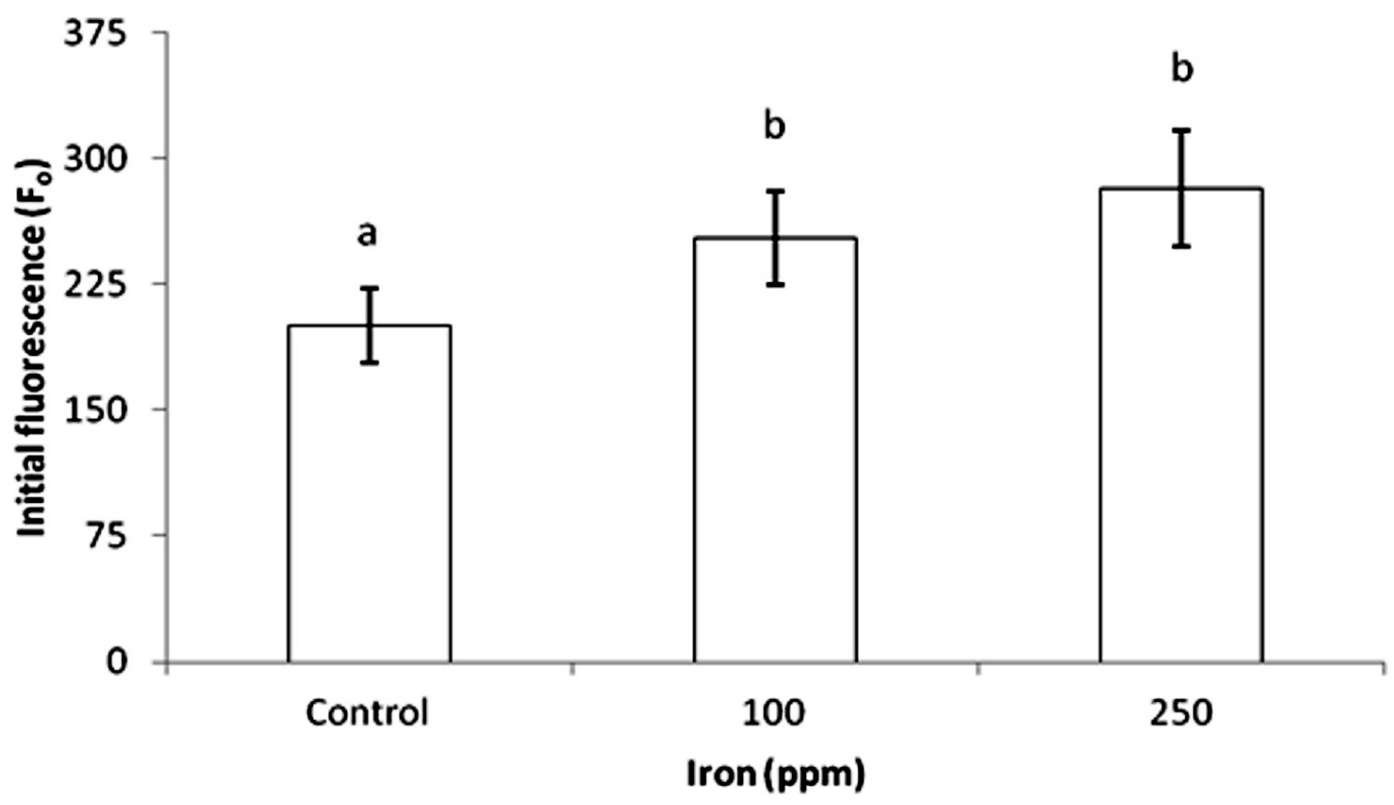

Figure 1. Minimum fluorescence $\left(F_{0}\right)$ in plants of Brassica oleracea var. Italica exposed to iron toxicity ( $\left.n=7\right)$. 
photochemical quenching coefficients ( $q \mathrm{~N}$ and NPQ) were determined, and from thesevariable fluorescence $\left(F_{v}\right)$ and maximum quantum efficiency of PSII (the ratio of $\left.F_{v} / F_{m}\right)$ were calculated.

The greenhouse was fitted with pipes and hoses to aerate the glass containers, with the purpose of oxygenating plants. Experimental units were laid out in a totally randomized design with seven replications of each of the three treatments. Results were subjected to analysis of variance (ANOVA), and treatments were compared using Tukey's range test at a significance level of $5 \%$. Statistical analyses were performed using version 19.0.0 of the IBM-SPSS statistics program (Statistical Product and Service Solutions, IBM Corporation, New York, USA).

\section{Results and discussion}

Minimum fluorescence showed significant differences between treatments $(p<0.05)$, progressively rising as iron content rose in the growing medium. The value for this variable was 26.0 and $40.6 \%$ higher in plants receiving 100 and 250 ppm Fe, respectively, as compared to the control (figure 1).

Initial fluorescence values $\left(\mathrm{F}_{\mathrm{o}}\right)$ can increase when there is some type of damage in the reaction centers of photosystem II (PSII) (Vieira et al., 2010), or due to a reduction in the transfer of excitation energy from the light harvesting complex to reaction centers (Baker and Rosenqvist, 2004). In the same way, the loss of reaction centers as a result of damage in the photosynthetic apparatus leads to an increase in the amount of energy emitted as $F_{o}$ (Conroy et al., 1986). Photoinhibition of PSII related to stress from iron excess is accompanied by the oxidative degradation of the D1 protein by light (Sárvári, 2005; Suh et al., 2002), and iron excess also causes deficiency of manganese, a crucial element for water oxidation by the OEC (oxygen evolving complex).

High iron concentrations in the growing medium reduce the concentration of ions such as $\mathrm{Ca}, \mathrm{Mg}$, and $\mathrm{P}$ in apical growing points and thus in plant leaves, which in turn affects the photosynthetic apparatus of plants, given that these nutrients are associated with the synthesis of proteins involved in the electron transport chain and other aspects of photosynthesis (Majeruset al., 2007). It can thus be assumed that magnesium deficiency due to excess iron leads to the synthesis of fewer primary reaction centers, and this raises initial fluorescence and decreases the ratio of $F_{v} / F_{m}$, because this parameter is highly sensitive to variations in $F_{o}$ and $\mathrm{F}_{\mathrm{m}}$.

Maximum quantum efficiency of PSII $\left(F_{v} / F_{m}\right)$ showed significant differences for the different treatments; this variable diminished as iron concentration was raised. Thus the ratio of $F_{v} / F_{m}$ was respectively 5.4 and $11.1 \%$ lower in plants under 100 ppm and 250 ppm Fe treatments as compared to control plants (figure 2).

Xing et al., (2010) found that maximum quantum efficiency of PSII in Spirodela polyrrhiza was reduced as iron concentrations were raised in the growing solution, reaching a level of 0 with an iron concentration of 100 ppm. By the same token, Suh et al. (2000) found

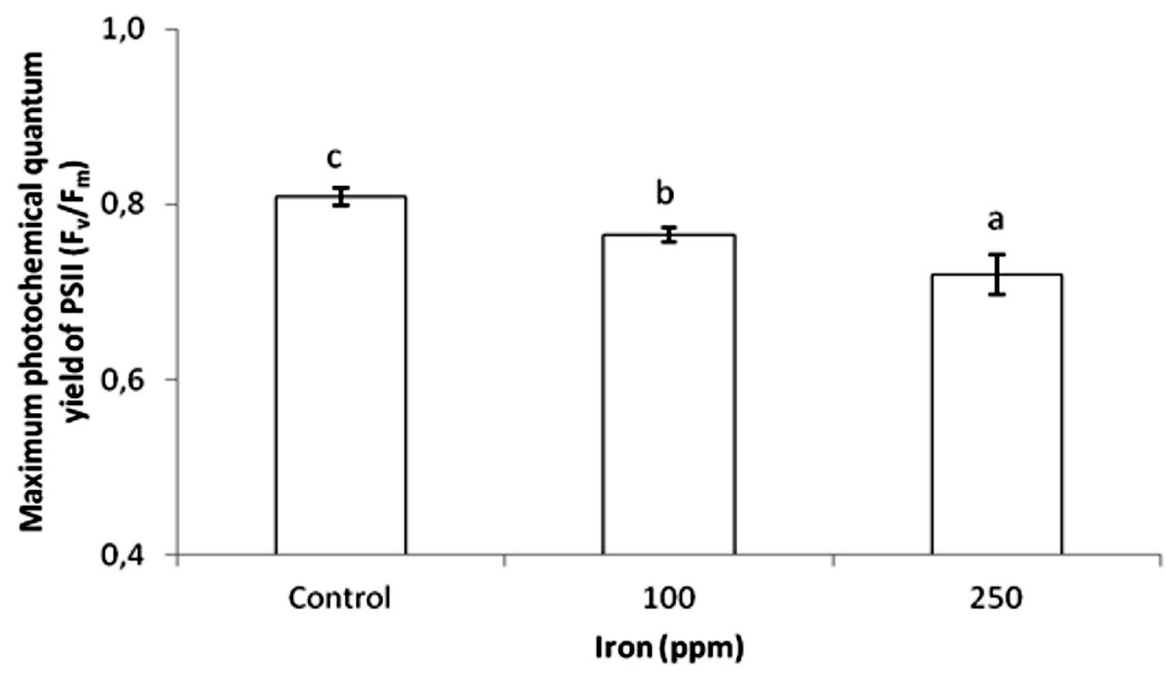

Figure 2. Maximum photochemical quantum yield of PSII $\left(\mathrm{F}_{\mathrm{v}} / \mathrm{F}_{\mathrm{m}}\right)$ in plants of Brassica oleracea var. Italica exposed to iron toxicity $(n=7)$. 
that in pea plants exposed to iron toxicity, the values of $F_{v} / F_{m}$ fell as compared to plants grown under optimum iron conditions. In both studies, the authors confirmed that this response of maximum quantum efficiency of PSII is due to the fact that high concentrations of the metal in plant tissues led to severe damage in the photosynthetic apparatus due to reactive oxygen species (ROS) (Xing et al., 2010), which changed fatty acid composition in thylakoid membranes and thus altered their integrity (De Vos et al.,1991). This would interfere with the biosynthesis of photosynthetic machinery, which of course would lower photosynthetic rate (Yruela, 2005).

Nenova (2006) found that 34 days after iron application in garden pea, maximum quantum efficiency of PSII $\left(F_{v} / F_{m}\right)$ showed no significant difference between treatments, though it did rise slightly until Fe concentration of $2 \mathrm{ppm}$, and began to decrease as iron concentration rose from 10 to $40 \mathrm{ppm}$. This author indicates that reductions in PSII maximum quantum yield are closely related to damage in the photosynthetic apparatus due to photoinhibition. In this same experiment, there were no significant differences found between treatments for other aspects of chlorophyll fluorescence, except for the efficiency in the capture of excitation energy. This implies that the iron levels used in the experiment were not sufficiently high or the exposure sufficiently prolonged so as to induce a strong inhibition in activity of photosystem II.

One of the present study's most important findings relates to electron transport rate. As seen in figure 3, significant differences $(p<0.05)$ were found between the three treatments evaluated. Plant exposure to iron toxicity induced a lower ETR in broccoli plants, with rates 40.5 and $67.6 \%$ lower in plants subjected to 100 and 250 ppm Fe, respectively, as compared to control plants.

Among the important symptoms related to iron toxicity are stunting (De Dorlodot et al., 2005), nutritional disorders (Genon et al., 1994), and perhaps most importantly, the overproduction of ethylene (Yamauchi and Peng, 1995). This last reaction is possibly the cause of a reduction in electron transport rate, since ethylene overproduction reduces the useful life of plant leaves, and thus their photosynthetic capacity. On the other hand, Prasad and Strzalka (1999) suggest that iron and copper excess induces oxidative stress in chloroplasts. When reactive oxygen species (ROS) reach levels that exceed a plant's ability to extinguish them, a peroxidation takes place in chloroplast membranes, which leads to a reduction in pigment concentration (Baszynski et al., 1988), causing a low efficiency in photon capture and there for in photosynthetic rate.

The photochemical fluorescence quenching coefficient $(\mathrm{qP})$ and the non-photochemical fluorescence quenching coefficient related to heat dissipation (NPQ) presented significant differences between treatments. Nevertheless, the coefficient $q \mathrm{~N}$, which includes all non-photochemical losses other than heat, showed no significant differences between treatments, possibly because, in the toxic conditions plants were exposed to, the most energetically economic way to release excess energy was heat. Plants growing with 100 ppm Fe in the substrate showed $\mathrm{qP}$ values $38.5 \%$ lower than controls, while plants in $250 \mathrm{ppm}$ Fe reduced qP by $69.8 \%$ as compared to control plants. NPQ was $36.8 \%$ lower in plants growing under 100 ppm Fe than in controls, and $67.3 \%$ higher in the 250 ppm treatment than in the control treatment (table 1).

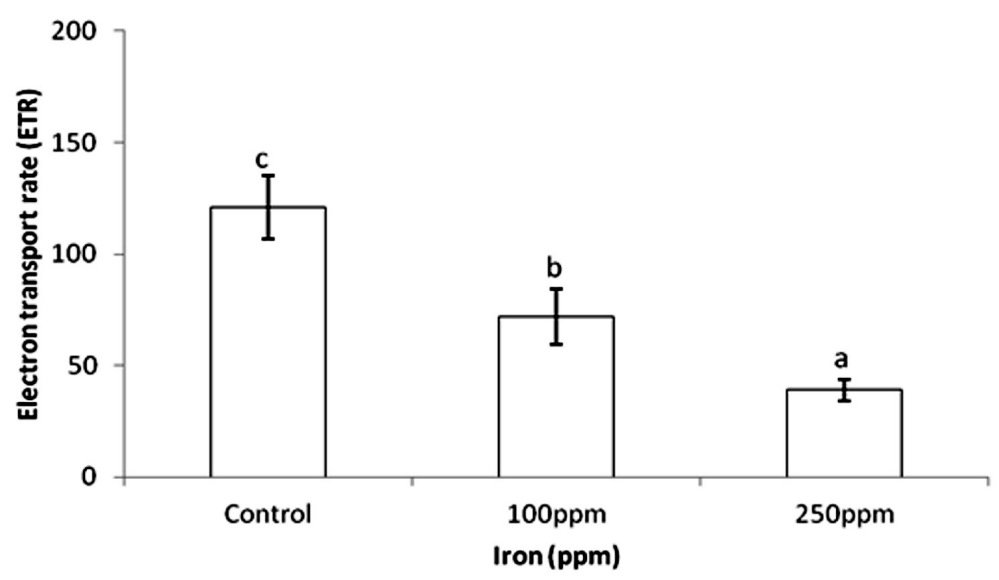

Figure 3. Electron transport rate (ETR) in Brassica oleracea var. Italica subjected to iron toxicity $(n=7)$. 
Table 1. Photochemical and non-photochemical quenching coefficients in plants of Brassica oleracea var. Italica exposedtoirontoxicity.

\begin{tabular}{|l|c|c|c|}
\hline \multirow{2}{*}{ Iron $(\mathbf{p p m})$} & $\begin{array}{c}\text { Photochemical } \\
\text { Quenching }\end{array}$ & $\begin{array}{c}\text { Non-Photochemical } \\
\text { Quenching* }^{*}\end{array}$ & $\begin{array}{c}\text { Non-Photochemical } \\
\text { Quenching }^{* *}\end{array}$ \\
\cline { 2 - 4 } & $(\mathbf{q P})$ & $(\mathbf{q N})$ & $(\mathbf{N P Q})$ \\
\hline Control & $0.54 \pm 0.14 \mathrm{c}$ & $0.52 \pm 0.03 \mathrm{a}$ & $0.65 \pm 0.26 \mathrm{a}$ \\
\hline 100 & $0.33 \pm 0.08 \mathrm{~b}$ & $0.47 \pm 0.15 \mathrm{a}$ & $0.41 \pm 0.09 \mathrm{a}$ \\
\hline 250 & $0.16 \pm 0.05 \mathrm{a}$ & $0.63 \pm 0.15 \mathrm{a}$ & $1.09 \pm 0.47 \mathrm{~b}$ \\
\hline
\end{tabular}

* Coefficient of non-photochemical fluorescence quenching

* Non-photochemical fluorescence quenching: quantification of non-photochemical quenching alternative to qN calculations. The extent of NPQ has been suggested to be associated with the number of quenching centers in the light-harvesting antenna.

In each column, different letters indicate significant differences by variance analysis $(p<0.05)$. $(n=7)$.

Regarding the photochemical quenching coefficient (qP), Nenova (2006) reported that 34 days after iron addition to pea plants, $\mathrm{qP}$ was at its maximum under a concentration of 40 ppm Fe. Nevertheless, the same author found that 41 days after application, qP remained at its highest level for $0.1 \mathrm{ppm}$ Fe, but that upon raising concentration to $40 \mathrm{ppm}, \mathrm{qP}$ decreased $2.3 \%$. Despite the fact that differences were not found to be significant, it is important to note that variations in this parameter are very sensitive, such that a small change can indicate a notable modification in excitation energy destined for primary photochemical reactions in plants. In the same respect, this author affirmed that NPQ (measured 41 days after iron application) rose as iron concentration was raised from 0 to $40 \mathrm{ppm}$ in the growing medium. This indicates a possible instance of photoinhibition, since maximum quantum efficiency of PSII also decreased. The above implies a higher dissi- pation of energy in plants grown under iron excess as a result of damage to the photosynthetic apparatus, which led to a reduction in $\mathrm{qP}$.

Effective photochemical quantum yield of PSII, or ФII, decreased as iron concentration increased. Thus 100 and $250 \mathrm{ppm}$ applications of Fe reduced this variable by 38.0 and $66.4 \%$ respectively as compared to control plants. Non-photochemical fluorescence quenching caused by factors other than reductions in light harvest $(\mathrm{Y}(\mathrm{NO}))$ also presented significant differences. Iron concentrations in the growing medium of 100 and $250 \mathrm{ppm}$ raised this variable by 44.1 and $41.6 \%$ respectively in comparison to control plants. For its part, non-photochemical fluorescence quenching due to a reduction in the light harvesting function, or $\mathrm{Y}(\mathrm{NPQ})$, showed no significant differences between treatments (figure 4).

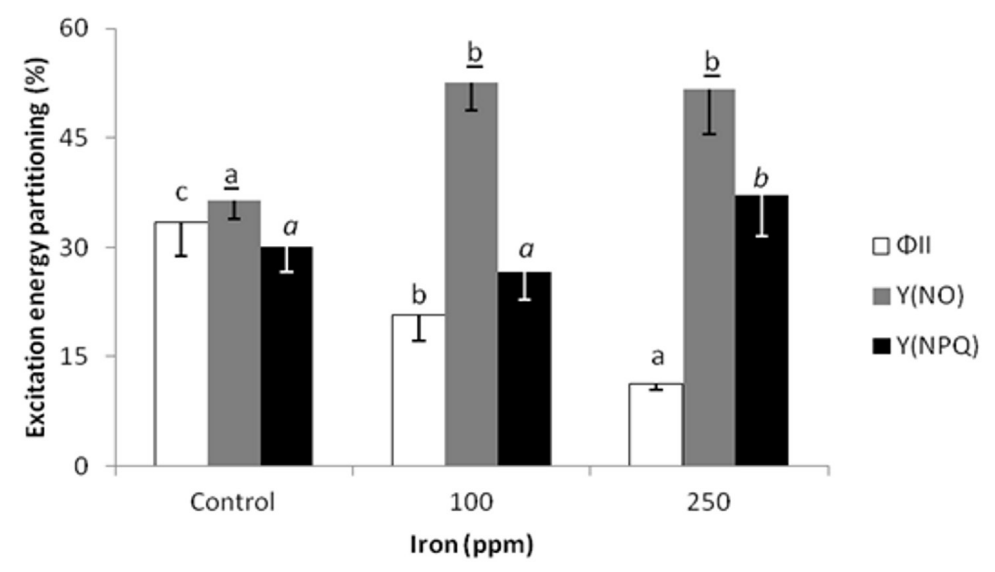

Figure 4. Excitation energy partitioning in Brassica oleracea var. Italica exposed to iron toxicity ( $n=7)$. 
Referring to excitation energy partition, Nenova (2006) found in garden pea that iron applications up to $2 \mathrm{ppm}$ increase effective photochemical yield of PSII $(\Phi I I)$, both at 34 days and 41 days after the onset of application. This was attributed principally to the fact that low doses of added Fe induce protein synthesis and contribute to the proper functioning of the photosynthetic apparatus. Nevertheless, when this mineral was increased to concentrations of 10 and $40 \mathrm{ppm}$ in the growing medium, these parameters began to decrease, and though there were no significant differences found, this reduction is pertinent to the discussion, since protein synthesis is hindered by iron toxicity. By the same token, iron excess causes manganese deficiency in plants, which obstructs the electron transport chain, thus lowering effective photochemical yield of PSII (ФII), while photochemical losses increase, indicating some type of stress on PSII. In the present study, the differences in $\mathrm{Y}(\mathrm{NO})$ may be related to the photoinhibition of photosystem II, since this parameter is linked to non-photochemical losses other than heat dissipation (measured in turn by $\mathrm{Y}(\mathrm{NPQ})$ ), which also showed significant differences. Non-photochemical fluorescence quenching caused by factors other than the reduction in the light capture function, or $\mathrm{Y}(\mathrm{NO})$, are linked to the loss of energy all along the electron transport chain, as well as to the destruction of the D1 protein in PSII

\section{Acknowledgments}

This study was carried out with the support of the Research Directorate (DIN) of the Technological and Pedagogical University of Colombia (UPTC), through the UPTC Young Researchers Program. It also received support from the Plant Ecophysiology research group of the Agricultural Engineering program of the Faculty of Agricultural and Animal Sciences of the UPTC.

\section{References}

Amézquita E. 1998. Propiedades físicas de los suelos de los Llanos Orientales y sus requerimientos de labranza. In: Romero G, Aristizábal D, Jaramillo C (Editores). Encuentro Nacional de labranza de Conservación. Memorias. Villavicencio. Colombia. pp.145-174.

Baker NR, Rosenqvist E. Applications of chlorophyll fluorescence can improve crop production strategies: an examination of future possibilities. Journal Experimental Botany, 2004; 55:16071621.

Baszynski T, Tukendorf A, Ruszkowska M, Skorzynska E, Maksymiec W. Characteristics of the photosynthetic apparatus of copper non-tolerant spinach exposed to excess copper. J. Plant Physiol, 1988;132:708-713.
Casierra-Posada F., Cárdenas-Hernández JF, Roa HA. Efecto del aluminio sobre la germinación de semillas de trigo (Triticum aestivum L.) y de Maiz (Zea mayzL.). Orinoquia, 2008;12(1):45-56.

Casierra-Posada F, Pachón CA, Niño-Medina RC. Análisis bromatológico en frutos de tomate (Lycopersicon esculentum Mill) afectados por salinidad por $\mathrm{NaCl}$. Revista U.D.C.A Actualidad y Divulgación Científica, 2007; 10(2):95-104.

Cochrane TT, Sánchez LF. Clima, paisaje y suelos de las sabanas tropicales de Suramérica. Inverciencias, 1981; 6:239-243.

Connolly E, Guerinot ML. Iron stress in plants. Genome Biology, $2002 ; 3(8): 1024$

Conroy JP, Smillie RM, Kuppers M, Bevege DI, Barlow EW. Chlorophyll a Fluorescence and Photosynthetic and Growth Responses of Pinus radiata to Phosphorus Deficiency, Drought Stress, and High $\mathrm{CO}^{2}$. Plant Physiol, 1986; 81: 423-429.

De Dorlodot S, Lutts S, Bertin P. Effects of ferrous iron toxicity on the growth and mineral composition of an interspecific rice. J. Plant Nutr, 2005; 28:1-20.

De Oliveira-Camargo CE. Tolerância de cultivares de arroz emestádio de plântula a diferentes níveis de ferro emsolução nutritiva. Bragantia, campinas, 1984; 43(2):369-380.

De Vos CHR, Schat H, De Waal MAM, Vooijs R, Ernst WHO. Increased resistance to copper-induced damage of the root cell plasmalemma in copper tolerant Silene cucubalis. Plant Physiol, $1991 ; 82: 523-528$.

Flor CA. 2010. Diagnóstico de problemas de fertilidad de suelos: visión actual. En: Degiovanni V, Martínez C, Motta F (Editores). Producción eco-eficiente del arroz en América Latina, tomo I. Centro Internacional de Agricultura Tropical, Cali. pp.336-349.

Genon J, De Hepcee N, Duffey J, Delvaux B, Hennebert P. Iron toxicity and other chemical soil constraints to rice in highland swamps of Burundi. Plant Soil, 1994; 166:109-115.

Gómez MI, Castro HE, Gómez CJ, Gutierrez OF. Optimización de la producción y calidad en cebolla cabezona (Allium cepa) mediante el balance nutricional con magnesio y micronutrientes (B, Zn y Mn), Valle alto del río Chicamocha, Boyacá. Agronomía Colombiana, 2007; 25(2): 339-348.

Majerus V, BertinP, Lutts S. Effects of iron toxicity on osmotic potential, osmolytes and polyamines concentrations in the African rice (Oryza glaberrima Steud.) Plant Science, 2007; 173:96-105.

Malagón-Castro D. 2011. Los suelos de Colombia. Sociedad Geográfica de Colombia. [20 de Enero de 2012]. URL: www.sogeocol.edu.co/documentos/05loss.pdf.

Molina DL, Amézquita E, Hoyos P. 2003. Construcción de capas arables en suelos oxisoles de la Altillanura colombiana. Evaluación de parámetros y procesos hidrológicos en el suelo. Escuela Latinoamericana de Física de Suelos. La Serena, Chile p.113-117.

Nenova V. Effect of iron supply on growth and photosystem II efficiency of pea plants. Gen. Appl. Plant Physiology, special issue, 2006:81-90.

Ponnamperuma FN. 1976. Screening rice for tolerance to mineral stress. In: Wright MJ(Editor). Workshop on plant adaptation to 
mineral stress in problem soils.Proceedings.Ithaca, Cornell University. Beltsville, Maryland. p. 341-353.

Prasad PVV. 2003. Iron chlorosis. Encyclopedia of applied plant sciences. pp. 649-656.

Prasad MNV, Strzalka K. 1999. Impact of heavy metals on photosynthesis. In: Prasad MNV, Hagemeyer J(Editors). Heavy Metal stress in Plants: from Molecules to Ecosystems. SpringerVerlag, Berlin-Heidelberg. pp 117-138.

Rodríguez-Atehortúa M, Rubiano-Sanabria Y, Silva-Brito JL, Rodrigues SC. La geología, geomorfología, pedología y uso de la tierra en las municipalidades de Puerto López (Colombia) Y Uberlândia (Brasil). Sociedad y Natureza, Uberlândia, 2010; 22(2):329-345.

Sahrawat KL. 2004. Managing iron toxicity in lowland rice: the role of tolerant genotypes and plant nutrients. Rice is life: scientific perspectives for the 21st century. In: Toriyama K,Heong KL, Hardy B (Editors.). Proceedings of the World Rice Research Conference. p. 452-454.

Sárvári É. 2005. Effects of Heavy Metals on Chlorophyll-Protein Complexes in Higher Plants: Causes and Consequences. In: Handbok of photosynthesis. 2da edición. Taylor y Francis Group, LLC.

Suh HJ, Kim CS, Jung J. photodynamic action by endogenous nonchlorophyll sensitizer as a cause of photoinhibition. Journal of Photoscience, 2000; 7(3):87-95
Suh HJ, Kim CS, Lee JY, Jung J. Photodynamic effect of iron excess on photosystem II function in pea plants. Photochem. Photobiol, 2002; 75:513-518.

Talbot RJ, Etherington JR, Bryant JA. Comparative studies of plant growth and distribution in relation to waterlogging. XII. Growth, photosynthetic capacity and metal ion uptake in Salix caprea and Salix cinerea ssp. oleifolia. New Phytologist, 1987; 105:563574.

Vieira DA de P, Portes T de A, Stacciarini-Seraphin E, Teixeira JB. Fluorescência e teores de clorofilas emabacaxizeiro cv. pérolasubmetido a diferentes concentrações de sulfato de amônio. Revista Brasileira de Fruticultura, 2010; 32(2):360-368.

Waldren S, Etherington JR, Davies MS. Comparative studies of plant growth and distribution in relation to waterlogging. $\mathrm{XV}$. The effect of waterlogging on growth of various populations of and hybrids between Geum rivale L. and Geum urbanum L. and soil chemical condition in experimentally flooded soil. New Phytologist, 1987; 105:551-562.

Xing W, Wang W, Liu G. Effect of excess iron and copper on physiology of aquatic plant Spirodela polyrrhiza (L.) Schleid. Environmental Toxicology, 2010; 25(2):103-112.

Yamauchi M, Peng XX. Iron toxicity and stress induced ethylene production in rice leaves. Plant Soil, 1995;173:21-28.

Yruela I. Copper in plants. Braz. J Plant Physiol, 2005; 17:145-156. 